\title{
THE LURE OF THE IMAGE: KEBOHONGAN PADA NARASI PEREMPUAN DALAM Syngué Sabour Pierre De Patience KARYA ATIQ RAHIMI
}

\author{
Yuli Mahmudah Sentana \\ Alumni Universitas Gadjah Mada \\ sentana@hotmail.fr
}

\begin{abstract}
Abstrak
Penelitian ini bertujuan untuk mengetahui posisi pengarang dalam narasi perempuan yang dituliskannya. Rahimi yang mengakui dirinya sebagai feminis, menuturkan bahwa ia menyuarakan suara-suara perempuan Afganistan melalui novel ini. Rahimi juga menawarkan sosok perempuan yang kuat di tengah belenggu patriarkal serta perempuan yang mampu melakukan perlawanan terhadap sistem patriakal. Permasalahannya adalah ambiguitas Rahimi dalam menarasikan perempuan sehingga memunculkan permasalahan. Untuk mengetahui posisi pengarang, penulis menggunakan konsep The Lure of The Image milik Lidia Curti. The Lure of The Image adalah sebuah tawaran yang diberikan oleh pengarang dalam memberikan posisi pada perempuan yang sebenarnya tidak diberikan oleh pengarang. Berdasarkan hasil penelitian yang dilakukan, hasil penelitian ini adalah Rahimi tetap membuat perempuan sebagai objek dalam dunia patriarkal. Dalam hal ini ia tidak mampu menarik perempuan keluar dari zona patriarkal. Ruang yang diberikan Rahimi untuk perempuan sebenarnya justru semakin mengukuhkan kekuasaan laki-laki. Dapat dikatakan bahwa apa yang dituliskan Rahimi dalam novel ini adalah sebuah The lure of The Image yang menurut Curti hanyalah sebuah gambaran perempuan yang dijanjikankan Rahimi pada perempuan semacam female gaze.
\end{abstract}

Kata Kunci: Narasi Perempuan, Female Gaze, Atiq Rahimi, Patriarkal, The Lure of The Image

\section{Abstract}

This study aims to determine the position of the author in women narration. With Rabimi's background as a feminist, he said that with his novel he voiced the voices of Afghan women. Rabimi offered a strong female figure in the middle of the patriarchal shackles who is able to fight the system. The problem of this study is Rabimi's ambiguity in narrating women. To determine the position of the author, the research uses the concept of the lure of the image belongs to Lidia Curti. The lure of the image is an offer provided by the author to give positions to women that are in fact not provided by them. Based on the research conducted, the results show that Rabimi keeps women as objects in a patriarchal world. In this case he is not able to pull the women out of the patriarchal zone. The space given to women by Rahimi reinforces male power. What Rahimi written in this novel is the lure of the image according to Curti's concept which explains it as an image of women given by author or known as female gaze.

Keywords: Woman Narration, Female Gaze, Atiq Rahimi, Patriarchal, The Lure of The Image

\section{Pendahuluan}

Syngué Sabour: Pierre de patience karya Atiq Rahimi ini menceritakan monolog seorang perempuan Afganistan yang sedang menjaga suaminya yang sedang koma. Kedaaan suaminya yang koma mampu membuat tokoh perempuan tersebut bisa bercerita dan melakukan apa saja yang tidak selama ini tidak dapat dilakukannya jika suaminya sadar. Melalui Syngué Saboure, Rahimi ingin menuliskan apa yang dirasakan oleh perempuan J'ai voulu me mettre dans la peau d'une femme" (Saya ingin menyelinap dalam kulit wanita) (Emmanuèle, 2013). Tidak hanya itu, Rahimi juga mempersembahkan novel ini kepada Nadia Anjuman. Nadia adalah seorang penyair asal Afganistan yang mati akibat kekerasan fisik yang dilakukan oleh suaminya. Ia selalu bertanya-tanya bagaimana seorang wanita bisa dipukuli oleh suaminya, kekasihnya, ayah dari anak-anaknya, terlebih oleh laki-laki 
baik, yang bukan berasal dari Taliban, serta berpendidikan ${ }^{1}$.

Sebagai yang menggangap dirinya sebagai feminis, novel ini adalah usaha Rahimi dalam membela perempuan. Beberapa penelitian pun mendukung pernyataan Rahimi tersebut. José Dominique de Almeida pada artikelnya Ecriture au feminim parprocuration Pierre de patience d'Atiq Rahimi mengatakan bahwa syngué sabour adalah usaha Rahimi menuliskan Afganistan dari daerah lain, yaitu Prancis. Walupun sebagian besar ia lebih melihat bagaimana tulisan Atiq Rahimi sebagai seorang francophoning mencoba memasuki sastra Prancis, Almeida tetap melihat bagaimana usaha Rahimi sebagai feminis. Baginya syngué sabour adalah sebuah pesan dan harapan mengenai kesetaraan gender.

Penelitian lain juga dilakukan oleh Diana Budi Darma, M.Pd dan Titik Hari Pangestu (2012) dengan judul "Confession without borders: 1st Wave Feminism against Woman's Right Disproportion in Atiq rabimi's The Patience Stone". Permasalahan yang terdapat dalam penelitian ini adalah mengenai dominasi laki-laki dan pengakuan perempuan sebagai cerminan dari feminisme gelombang pertama. Hasil dari pertanyaan penelitian pertama adalah hidup dalam lingkaran patriarki, membuat wanita tidak dapat melakukan apa pun yang mereka inginkan. Namun demikian diamnya perempuan adalah sebuah bentuk pertahanan atau pelindungan diri dari pada melawan lakilaki. Kesimpulannya, perempuan telah dapat melawan pariarki menurut penelitian ini.

Penelitian selanjutnya dilakukan oleh Halimah Nur Sa'aadah (2014), dengan judul "Perjuangan Eksistensi Perempuan dalam Novel Syngué Sabour-Pierre de patience Karya Atiq Rabimi". Permasalahan dalam penelitian ini adalah, sistem apa yang dilawan oleh tokoh perempuan dalam novel ini, dan bagaimana perjuangan perempuan untuk memperoleh eksistensi diri sebagai manusia yang utuh di dalam novel ini? Hasil dari penelitian ini adalah, perempuan dalam novel ini melawan budaya

\footnotetext{
${ }^{1}$ Suami Nadia, pelaku kekerasan adalah laki-laki baik-baik, bukan kriminal. Ia juga bukan seorang Taliban, yang terkenal gemar memukul wanita mereka. Ia juga berasal dari kalangan berpendidikan.
}

patriarki dan perjuangan yang dilakukan oleh tokoh perempuan tersebut adalah kebebasan berpikir dan berbicara.

Lidia Curti yang merupakan feminis asal Italia mengatakan bahwa dalam fiksi semuanya bersifat tak terbatas dan batasbatas yang ada di dalamnya tidak jelas. Ketika penulis menuliskan mengenai perempuan, perlu diperlihatkan apakah ia menulis mengenai perempuan 'yang sebenarnya' atau hanya menulis mengenai gambaran mengenai perempuan ${ }^{2}$. Baginya monster yang sebenarnya adalah yang menulis perempuan yang 'tak nyata. Curti menjelaskan bagaimana dalam sebuah cerita perempuan masih harus dilihat lebih lanjut apakah cerita tersebut benar-benar berada di pihak perempuan. Di sini lah Curti mengenalkan kita pada female gaze. Sebuah cerita atau serial naratif yang dibuat guna menyenangkan perempuan. Dalam hal ini Curti mencontohkan sebuah serial Charlie's Angels, di mana tokoh utamanya adalah tiga perempuan. Serial tersebut tidak hanya menggambarkan persahabatan dan solidaritas yang kuat antara para perempuan tetapi para perempuan tersebut juga digambarkan sebagai sosok yang sangat berbeda. Jika perempuan adalah lemah atau laki-laki adalah sosok pemberantas kejahatan maka serial ini membuat kebalikannya. Tiga perempuan tersebut adalah para perempuan kuat dan cerdas dalam memberantas kejahatan. Mereka digambarkan sebagai agen perempuan yang tidak terkalahkan. Namun semua kekuatan para perempuan tersebut terdapat tokoh Charlie yang tidak terlihat namun merupakan sosok utama di mana ia adalah boss atau seseorang yang harus dipatuhi oleh tiga perempuan hebat tersebut. Hal ini merupakan sebuah contoh female gaze dimana penonton perempuan dibuat terbuai oleh hebatnya tiga tokoh perempuan tersebut.

Dalam narasi perempuan, perempuan diberi sebuah iming-iming mengenai citra mereka. Curti mencontohkan serial Absolutely

\footnotetext{
2 Bagi Curti, beberapa filsuf berbicara mengenai perempuan namun tidak pernah berbicara mengenai 'the real women'. Curti juga mengkritisi cerita mengenai perempuan yang muncul di media massa yang lebih menekankan pada 'the images of women' dari pada 'the real women'.
} 
Fabulous $^{3}$ yang mengisahkan persahabatan dua perempuan yang pemabuk berat dan pemakai narkoba. Pengarang menawarkan sebuah stereotip lain mengenai perempuan. Pengarang memunculkan dua perempuan yang lucu dan pemabuk namun di sisi lain sangat mandiri dan tidak tergantung pada laki-laki. Pada contoh tersebut perempuan diberikan sebuah citra yang mandiri walaupun dianggap sebagai sosok yang menyimpang dalam masyarakat. Dimana dalam narasi perempuan terkadang perempuan masih menjadi objek yang pantas dipertontonkan. Curti mencontohkan serial Capitol, yang terdapat tokoh perempuan Kelly Harper yang cemas dan tertekan, sebagai ibu tunggal dan sebagai simpanan laki-laki. Kegalauannya membuatnya terjun pada minuman keras dan narkoba. Pada kasus ini kesedihan dan permasalahan perempuan dijadikan sebagai sebuah tontonan yang menarik. Dengan demikian, dalam narasi perempuan terdapat ambiguitas di dalamnya, apakah pengarang terutama para feminis masih mempertahankan pembelaannya pada perempuan dengan tidak menjadikan perempuan sebagai objek belaka atau justru masih menjadikan perempuan sebagai objek dalam tulisannya.

Melalui syngué sabour, Rahimi mencoba menyuarakan suara perempuan. Rahimi menggambarkan kehidupan perempuan Afganistan melalui tokoh perempuan yaitu $\mathrm{La}$ femme yang terkungkung dalam genggamanlakilaki. Hidup dengan budaya patriarki membuat perempuan kehilangan haknya untuk bersuara atau bernarasi. Perempuan Afganistan, menurut Rahimi sama saja dengan perempuan lainnya, memiliki tubuh, mimpi, keinginan, kesenangan. Namun dalam masyarakat yang didominasi lakilaki, semuanya tidaklah mungkin. Selanjutnya, ada seorang perempuan yang merasakan hal ini, ia ingin berbicara. Namun, sebelumnya ia perlu untuk melumpuhkan sistem diktator ini. Melalui tubuh lebam suami serta lumpuhnya sang suami, nampak lah kesempatan itu (Pierre, 2013).

Dengan kuatnya sistem patriarki, Rahimi perlu meruntuhkan sistem ini untuk

\footnotetext{
${ }^{3}$ Sebuah sitcom yang tayang pada tahun 1992-2012
}

membuat perempuan dapat bernarasi. Ia membuat suami La femme menjadi koma dan tak berdaya. Keadaan laki-laki yang tak berdaya ini membangkitkan keberanian perempuan untuk bernarasi. Dalam narasinya, perempuan dibuat pengarang menjadi sebagai sosok yang superior, sosok yang mampu berbicara apa saja, bahkan hal yang tabu atau tidak seharusnya dibicarakan oleh perempuan. Perempuan yang merupakan sosok yang selalu berada di bawah kekuasaan laki-laki di Afganistan. Lewat narasi yang dimonologkan oleh tokoh La femme, Rahimi ingin membuktikan bahwa perempuan juga dapat melawan laki-laki. Perlawanan yang dilakukan perempuan diawali dengan membicarakan laki-laki. Narasi-narasi yang muncul lewat suara perempuan ini juga berbicara tentang laki-laki, mengkritik laki-laki, dan menyalahkan laki-laki atas semua yang telah terjadi.

Dalam novel Syngué Sabour: Pierre de patience pengarang menarasikan bahwa di dalam dunia patriarkal perempuan bukanlah sosok yang lemah, perempuan sebenarnya dapat melawan kekuasaan laki-laki. Pengarang juga menggambarkan laki-laki sebagai sosok lemah yang takut dan menderita. Akan tetapi, terdapat fakta lain bahwa dalam novel tersebut perempuan hanya dapat bernarasi saat laki-laki tidak berdaya. Pengarang ingin menyatakan bahwa perempuan adalah sosok yang kuat namun ia juga menjadikan perempuan lemah. Dengan the lure of the image, tulisan ini mencoba mengungkapkan bagaimana posisi pengarang dalam menarasikan perempuan sebagai usahanya membela perempuan.

\section{Otonomi Perempuan terhadap Laki-laki}

Dengan kuatnya sistem patriarkal di Afganistan membuat perempuan menjadi tidak memiliki kekuatan atau kekuasaan. Menurut Rahimi perempuan Afganistan sama dengan perempuan lainnya, memiliki tubuh, mimpi, keinginan, kesenangan, akan tetapi dominasi laki-laki yang kuat membuat segalanya tidaklah mungkin. Namun demikian, sebagai seorang feminis Rahimi ingin menunjukkan bahwa perempuan dapat melawan dan dapat berbicara. Seperti pada wawancaranya bahwa 
sebelum membuat seorang perempuan berbicara Rahimi perlu untuk melumpuhkan sistem diktator ini (Pierre, 2013). Melalui tubuh lebam suami, serta lumpuh nampaklah kesempatan itu. Keadaan komanya sang suami, membuat Rahimi memberikan kesempatan pada perempuan untuk berbicara. Melalui teks, ia menyuarakan suara-suara perempuan yang ingin diperdengarkan pada laki-laki, pada dunia. Bahwa kuatnya sistem patriarkal di Afganistan ini dapat ditembus dan didobrak oleh perempuan.

"Voilà où t'a amené ton âme! Un cadavre vivant!" Elle s'approche de la cachette: "C'est ta maudite âme qui te cloue à terre, ma syngué sabour!", repr|end son souffle, "et ce n'est pas ton âme à la con qui audjourd'bui, me protège. Ce n'est pas elle qui nourrit les enfants". Elle écarte le rideau".

"Nah, beginilah sekarang jiwamu! Mayat hidup!" Ia mendekati tempatpersembunyian itu: "Jiwa terkutukmu lah yang memangkumu ditanah, Syngué sabour-ku!, ia kembali menarik napas, "Dan sekarang, bukan jiwa tololmu itu yang melindungiku, menghidupi anakanak". Ia menyibak tirai itu. "Kau tabu bagaimana jiwamu sekarang? Di mana ia? Jiwamu di sini, tergantung tepat di atasmu". Ia menunjuk ke arah kantong infus (Rahimi, 2004: 134).

Pada penggalan novel di atas menunjukkan bahwa laki-laki yang tidak berdaya membuat perempuan berani berbicara, tidak hanya berbicara mengenai dirinya tetapi juga mengkritik suaminya. Penggalan di atas juga menyimpulkan bahwa perempuan dinarasikan sebagai perempuan yang mandiri. Kemampuannya untuk mandiri membuatnya mampu dan berani untuk menghina suaminya. Selama ini perempuan memahami bahwa laki-laki adalah pelindung mereka. Sebagai pelindung mereka pantas berbuat apa saja pada perempuan dan perempuan harus menerimanya. Kemandirian yang dapat dilakukan oleh $L a$ femme membuatnya tersadar bahwa ia dapat hidup tanpa bergantung pada laki-laki. Saat jiwa laki-laki yang selama ini ia kagumi dan jiwa yang selama ini melindunginya terbaring lemah, membuatnya tersadar bahwa jiwa itu tidak dapat lagi melidunginya. Tidak hanya itu, ia pun mulai berani merendahkan laki-laki yang selama ini ia agungkan. Laki-laki yang selama ini merupakan tempatnya menggantungkan hidupnya kini terbaring tak berdaya bahkan bergantung padanya, pada cairan infus yang diberikan padanya.

Keberanian perempuan menghina lakilaki tidak hanya menunjukkan ketidakmampuan laki-laki menjaga perempuan seperti yang selama ini diwacanakan, tapi juga pada ketololan jiwa mereka. Kelemahan jiwa lakilaki tidak sebanding dengan kesombongan mereka terutama pada perempuan. Bagi La femme kesombongan laki-laki dan sikap semenamena laki-laki terhadap perempuan tidak setara dengan kelemahan mereka. Kekonyolan yang tidak perlu terjadi adalah penyebab peluru menembus leher suaminya. Bagi La femme, hal itu merupakan kebodohan suaminya. Pahlawan yang berperang di medan perang harus koma karena berkelahi dengan temannya. Dengan menyebut jiwa suaminya dengan sebutan tolol membuat perempuan merasa bahwa jiwa laki-laki tidak hanya lemah dan tidak mampu melindungi perempuan tapi juga menyatakan bahwa perempuan tidak membutuhkan perlindungan laki-laki.

".... Vous les hommes! Quand vous avez des armes, vous oubliez vos femmes"

"... Kalian para lelaki! Kalian melupakan perempuan kalian saat kalian memiliki senjata" (Rahimi, 2004: 67).

Perempuan pada penggalan di atas dinarasikan sebagai perempuan kesepian sehingga menjadi merana. Tidak hanya kesepian secara fisik tapi juga secara mental. La femme tidak hanya merasa kesepian ketika ditinggal suaminya perang namun kehadiran suaminya pun tidak dapat mengobati kesepiannya. Ia adalah perempuan yang merindukan kasih sayang, kasih sayang dari seorang suami. Sebagai negara yang dilanda perang, laki-laki di Afganistan diharuskan untuk angkat senjata. Dampak dari wajib angkat senjata tersebut memunculkan kisah mengenai senjata. Kisah 
bahwa senjata itu harus dijaga oleh para prajurit atau para lelaki karena senjata yang mereka bawa bukanlah senjata melainkan ibu mereka, saudara perempuan mereka, istri mereka, atau kehormatan mereka. Para lelaki harus menjaga senjata mereka selayaknya itu adalah ibu mereka, saudara perempuan mereka, istri mereka atau kehormatan mereka. Sebagai negara Islam yang menganggap bahwa perempuan harus dijaga mereka membuat simbol bahwa senjata adalah perempuan yang harus dijaga. Ironisnya, saat telah pulang dari perang mereka melupakan makna yang sesungguhnya. Para prajurit itu lupa pada perempuan yang sesungguhnya harus mereka jaga. Mereka melupakan perempuan mereka.

Sebagai kaum minoritas di Afganistan, perempuan seringkali tidak memiliki hak, hak berbicara, hak berpendapat, hak untuk melakukan sesuatu hal yang ia sukai atau inginkan. Sebagai upaya membuat perempuan kuat atau tidak lemah Rahimi menarasikan perempuan yang dapat mendobrak sistem patriarkal di Afganistan.

"J'ai touvé ma tante. Elle est allés dans le nord de la ville, un endroit plus sûr, chez, son cousin"... "I'ai laissé les enfants auprès d'elle....".

"Bodhi telah menemukan bibiku. Dia pergi ke utara kota, tempat yang lebih aman, di rumah sepupunya".... "Bodhi meninggalkan anak-anak padanya..." (Rahimi, 2004: 59).

Pada penggalan di atas juga terlihat bagaimana perempuan dapat memutuskan sesuatu dengan sendirinya tanpa persetujuan suaminya. Dengan situasi perang yang tidak menentu membuatnya ketakutan dan khawatir sehingga ia memutuskan mencari bibinya. Ia tidak hanya pergi mencari bibinya tetapi tanpa persetujuan suaminya membawa anak-anaknya dan menitipkan pada bibinya. Pendeskripsian perbuatan perempuan di sini menunjukkan kemandirian perempuan jika mereka tidak berada di bawah bayangbayang laki-laki. Rahimi ingin menunjukkan bahwa perempuan juga dapat memutuskan dan melakukan sesuatu demi yang terbaik bagi mereka. Perlawanan mereka juga ditunjukkan dengan bebasnya dan tanpa rasa bersalahnya perempuan melawan peraturan yang ada.

Ketidaksadaran laki-laki membuat perempuan berani berbicara bahkan membicarakan rahasia yang tidak ingin ia ungkapkan. Rahasia lain diungkapkan oleh $L a$ femme pada suaminya adalah bahwa anak yang mereka miliki bukanlah anak suaminya. Kutipan berikut adalah pengakuan dari La femme.

"Parce que cette enfant n'était pas de toi!... Oni, ma syngué sabour, ces deux filles ne sont pas les tiennes!". Elle se redresse. "Et tu sais pourquoi? Parce que c'était toi qui étais stérile. Pas moi!".

"Karena anak ini bukanlah anakmu!... Ya, syngué sabour-ku, kedua anak perempuan ini bukanlah anakmu!". Ia kembali berdiri tegak. Kau tabu kenapa? Karena kaulah yang mandul. Bukan Bodhi!" (Rahimi, 2004: 157).

La femme dan suaminya memiliki dua orang putri. Setelah lima bulan pernikahan $L a$ femme tidak jua kunjung hamil menyebabkan ibu mertuanya menginginkan agar suaminya menikah lagi. Namun pada akhirnya La femme hamil sehingga sang suami tidak menikah lagi. Pengakuan La femme kali ini merupakan pengakuan terbesar yang mungkin akan memberikan dampak besar baginya. Ya, ia mengungkapkan bahwa selamainiibu mertuanya salah. Selama masa penantian kehamilannya ibu mertuanya ingin suaminya menikah lagi karena La femme mandul. Pada penggalan ini La femme mengatakan bahwa bukan ia yang mandul melainkan suaminya. Ia mengatakan bahwa anak yang mereka miliki bukanlah anak suaminya, melainkan anaknya dengan laki-laki lain. Pengakuan ini tidak hanya mengungkapkan rahasia yang selama ini ingin ia pendam, namun juga keberaniannya melawan ajaran agama dan adat istiadat serta menunjukkan kecerdikan dan kekuatan menghadapi masalah bahkan sebelum suaminya koma.

Perempuan di sini dinarasikan sangat berbeda oleh Rahimi. Perempuan Afganistan yang terjerat oleh kultur sebagai kelas kedua yang tidak memiliki kekuasaan atau kekuatan untuk melawan laki-laki di sini diceritakan 
sebagai perempuan yang berani dan memiliki kekuatan untuk melawan, melawan lakilaki dan melawan sistem sosial. La femme yang tidak ingin dibuang oleh suaminya dan tidak ingin bernasib seperti bibinya yang dibuang oleh suami dan keluarganya mencari cara agar hal itu tidak terjadi. Ia melakukan apa pun agar keinginannya tercapai bahkan melakukan hal sangat dilarang oleh agamanya dan ditentang oleh sistem sosialnya. Resiko besar tidak menghalanginya untuk melakukan hal itu. Kewajiban untuk memiliki keturunan namun kehamilan yang tak kunjung datang membuatnya mendatangi germo bibinya. Pada akhirnya ia melakukan bersetubuh dengan pria lain hingga hamil. Di Afganistan perempuan yang diketahui melakukan zina akan dirajam hinggamati. Hingga kini banyak sekali korban perkosaan yang mengakibatkan perempuan dihukum hingga mati atau dibuang oleh keluarga dan lingkungannya. Namun, mereka melupakan bagi para laki-laki, pelaku pemerkosa karena banyak pelaku pemerkosa yang justru bebas dari hukuman. Mereka hanya fokus menghukum pihak perempuan, yang dianggap sang penggoda, sang pendosa. Dengan risiko yang begitu besar tetap tidak mengurangi keberanian La femme agar ia dapat hamil.

Kenyataan bahwa La femme memiliki dua orang anak, yang tidak seumuran yang membuktikan bahwa mereka bukan anak kembar menjadi fakta bahwa ia tidak hanya sekali mendatangi tempat germo tersebut. Jika pada pertama kali ia mungkin melakukan dengan penuh tekanan namun dengan adanya anak kedua membuktikan bahwa ia memiliki keberanian untuk melakukannya lagi setelah kelahiran anak pertamanya. Perempuan yang seharusnya takut untuk melakukan perzinaan namun di sini perempuan dibuat tidak mengenal takut, takut terhadap dosa atau terhadap risiko hukuman sosial yang akan ia terima bila ia ketahuan. Hal lain yang ingin ditunjukkan oleh Rahimi adalah bagaimana laki-laki yang merupakan sosok kuat tersebut tidak dapat memberikan keturunan.

Pada penggalan tersebut Rahimi tidak hanya menunjukkan kelemahan laki-laki tetapi juga membuat perempuan dapat menghina laki-laki. Laki-laki dalam sistem patriarkal yang tidak dapat mencium seorang perempuan atau memberikan ciuman yang diimpikan oleh perempuan. Bahkan tidak dapat memuaskan atau memberikan kenikmatan seksual pada perempuan. Penghinaan ini tidak hanya untuk melemahkan laki-laki tapi juga menunjukkan bahwa perempuan juga dapat memiliki hasrat seksual lebih tinggi dari laki-laki. Terlebih saat Rahimi membuat laki-laki tidak dapat memberikan keturunan atau mandul. Memiliki keturunan adalah hal yang sangat penting bagi masyarakat Afganistan sebagai sebuah simbol dapat meneruskan generasi baru. Akan tetapi dengan membuat laki-laki yang mandul bukan perempuan, Rahimi seakan memberikan ruang bagi perempuan untuk melawan lakilaki. Perlawanan ini ditunjukkan dengan keberaniannya memperoleh anak dari laki-laki lain.

\section{Syngué Sabour: Sebuah Iming-iming untuk Perempuan?}

La femme tokoh utama dalam novel ini dinarasikan sebagai seorang perempuan religius namun juga berani melanggar ajaran agamanya dan peraturan sosial yang mengikatnya. Sebagai perempuan religius ia selalu melakukan sembahyang, membaca Al Quran setiap hari serta berzikir dan berdoa demi kesembuhan suaminya. Tidak hanya itu, ia juga selalu bersikap hormat dan patuh terhadap suaminya, ibu mertuanya maupun saudara-saudara suaminya. Namun dengan keadaan suami yang koma, Rahimi ingin memunculkan sisi liar dari perempuan dengan membuatnya berani melawan sistem patriarkal serta melawan adat budayanya.

Pada novel ini Rahimi tidak hanya membuat perempuan berani melawan sistem patriarkal tetapi juga membuat perempuan berani melawan adat budayanya dan agamnya. Hal ini ditunjukkan saat ada prajurit belia yang mengiranya pelacur dan perempuan menerimanya dan kemudian mereka melakukan hubungan seksual berkali-kali. Perbuatan perempuan di sini tidak hanya berani mengkhianati suaminya tapi juga 
berani melanggar ajaran agama yang melarang perzinaan. Di sini perempuan dibuat berani melawan adat dan seakan perbuatannya ini mencerminkan pembalasan pada suaminya yang tidak dapat memberikan kepuasan seksual padanya. Akan tetapi di tengah La femme melakukan hubungan seksual dengan prajurit belia itu ia merasa sedih.

"La femme, silenciesuse, lance un regard infinitement triste vers la fente du rideau vert".

"Perempuan itu, tanpa suara, melemparkan pandangan sedih yang tiada tara pada celah tirai bijau" (Rahimi, 2004: 122)

Pada penggalan di atas menyebutkan bahwa saat perempuan melakukan perbuatan zina yang dianggap sebagai bentuk perlawanan perempuan terhadap ajaran agamanya, suaminya, serta sistem patriarkal sebenarnya perempuan tersebut tidak dapat melawan. Kesedihannya saat melakukan itu mengukuhkan bahwa sebenarnya ia masih mengingat Tuhannya, suaminya dan menyadari bahwa tindakannya tersebut adalah salah. Hal ini menunjukkan sifat religiusnya dan menghancurkan perlawanannya.

Pada syngué sabour, Rahimi membuat laki-laki koma dan tak berdaya agar perempuan dapat berbicara dan bertindak bebas. Ia memberikan ruang bagi perempuan dengan komanya laki-laki dan diharapkan perempuan memiliki otoritas penuh tidak seperti saat laki-laki ada dan tersadar. Sehingga perlu dilihat lebih dalam apakah narsai yang ditulis Rahimi ini merupakan pembelaannya terhadap perempuan.

Ketidakberdayaan laki-laki membuat perempuan bebas dalam melakukan apa saja. Jika selama ini perempuan harus tunduk dan patuh pada laki-laki termasuk jika ingin keluar rumah harus didampingi dan harus meminta izin dari suami. Maka dengan suami yang koma perempuan tidak perlu melakukan hal tersebut. La femme pada novel ini ditunjukkan dapat pergi keluar rumah dengan bebas, seperti mencari bibinya dan pergi ke apotek. Namun bukan berarti otoritas laki-laki atas perempuan hilang. Tak berdayanya tubuh laki-laki tidak menandai tak berdayanya kekuasaannya. Berikut ini adalah kutipan dari novel:

"Elle attend encore... la permission, peut-être".

"Dia masih menunggu... izin, mungkin" (Rahimi, 2004: 14)

Rahimi ingin menunjukkan bahwa perempuan dapat melawan melalui narasi-narasi yang dilontarkan oleh perempuan. Akan tetapi dalam narasi-narasi yang dibicarakan oleh perempuan memunculkan kenyataan lain bahwa sebenarnya perempuan tetaplah objek laki-laki. Rahimi memunculkan fakta bahwa perempuan masih berada dalam belenggu patriarkal.

Keadaan koma suaminya membuatnya mampu melakukan apa yang tidak dapat ia lakukan saat suaminya tersadar. Dengan suami yang koma ia mampu menyampaikan hasrat seksualnya.

"Sa main caresse les cheveaux de l'homme. "Te peux te toucher... tu ne m'as jamais laissé te toucher, jamais!" se glisse vers la bouche de l'homme. "Te ne t'ai jamais embrassé". Elle l'embrasse. "La première fois que j'ai voulu te donner un baiser sur les lèvres, tu m'as repoussée. E voulais faire comme dans les films indiens. Tu avais peir, peut-être, c'est ça?" l'interroge-t-elle d'un air amusé.... Ses lèvres caressent la barbe drue".

"Tangannya membelai rambut sang lelaki. "Bodhi bisa menyentubmu... Kau tak pernah membiarkanku membelaimu, tak pernah!” Tangannya meluncur menuju mulut sang lelaki. "Bodhi tak pernah menciummu". Ia menciumnya. "Saat pertama kali Bodbi ingin mencium bibirmu, kau menolakeu. Bodhi ingin melBodhikannya seperti yang ada di film India. Kau tBodhit, mungkin, itukah? Selidiknya dengan wajah geli....Bibirnya mengelus-elus janggut lebatnya" (Rahimi, 2004: 79-80).

Pada penggalan novel tersebut La femme dapat mencium suaminya seperti yang selalu diinginkannya seperti dalam film India. Ia dapat membelai suaminya, rambutnya, janggutnya. Perempuan menjadi memiliki kekuatan saat laki-laki sedang tak berdaya. Dengan membuat perempuan dapat mencium suaminya yang selama ini tidak dapat ia lakukan saat suaminya 
tersadar membuat perempuan dapat melakukan perlawanan atau dapat berkuasa atas tubuh lakilaki saat laki-laki sedang tidak berdaya.

Perlawanan lain yang dilakukan perempuan pada laki-laki adalah masturbasi. Disebabkan hasrat seksualnya yang tidak terpenuhi, La femme bermasturbasi untuk memuaskan hasratnya. Kegiatan ini bahkan dilakukannya sebelum suaminya koma.

"Une nuit, tu m'as surprise. Tu dormais. Mais, dos à toi, je me caressais. Mon halètement t' a peut-être réveillé. En sursautant, tu m' a demandé ce que je faisais. J'avais chaud, et je tremblais... Alors, je t'ai dit que j'avais de la fière. Tu m'as crue...".

"Suatu malam, kau mengejutkanku. Kau sedang tidur. Bodbi, memunggungimu, sedang bermasturbasi. Mungkin napasku yang terengahengah membangunkanmu. sambil melompat, kau bertanya-tanya apa yang sedang Bodhi IBodhikan. Bodhi kepanasan, dan Bodhi gemetar... Jadi Bodhi bilang padamu bahwa Bodhi terserang demam. Kau mempercayaiku..." (Rahimi, 2004: 127-128)

Persoalan seksualitas masih tabu untuk dibicarakan di Afganistan apalagi untuk kaum perempuan. Dengan kemampuan untuk membicarakan persoalan tersebut membuat perempuan seperti dapat melawan struktur sosial yang telah terbentuk. Keberanian perempuan untuk memuaskan dirinya dengan bermasturbasi membuatnya berbeda, membuatnya berani. Terlebih saat kegiatan tersebut dilakukan sebelum suaminya koma, saat laki-laki masih berkuasa. Ia melakukannya tanpa takut terlihat hina. Pada penggalan di atas diceritakan bahwa La femme dianggap berani melawan laki-laki karena masturbasi yang merupakan hal tabu tapi La femme sudah dibuat telah berani melakukannya. Bahkan pada saat sang lelaki telah koma La femme kembali berani bermasturbasi di depan suaminya. Ia bermasturbasi di depan suami yang koma serta sambil menyentuh suaminya. Hal ini tertuang dalam kalimat berikut.

"Est-ce que tu peux...?" Elle met sa main à l'intérieur du pantalon de l'bomme. Son autre main se perd entre ses propres cuisses. Ses lèvres effleurent la barbe, frôlent la bouche entrouverte. Leurs souffles se fondent, se confondent. "J'en rêvais... toujours. En me touchant, j'imaginais ta queue entre mes mains".

"Apa kau bisa...? Dimasukekannya tangannya ke dalam celana panjang sang lelaki. Tangan yang lain menghilang di antara kedua pahanya sendiri. Bibirnya mencecah janggutnya, menyentuh sekilas bibirnya yang setengah terbuka. Napas mereka melebur, memadu menjadi satu. "Selalu... kuimpikan. Sambil menyentuh diriku, kubayangkan punyamu di dalam tanganku". (Rahimi, 2004: 152)

Pada kalimat di atas terlihat bahwa keberanian La femme dalam melawan sistem patriarkal sangat jelas, ia melakukan hal yang selama ini menjadi hasratnya namun sangat terlarang dan tidak mungkin ia lakukan. Keadaan koma sang suami membuatnya mampu melakukan hal tersebut. Dengan bermasturbasi menunjukkan bahwa ia adalah perempuan mandiri karena mampu memberikan kenikmatan yang tidak ia peroleh dari suaminya. Akan tetapi Rahimi juga memunculkan hal lain.

"Pardon... Qu'est-ce qui me prend encore?....Je suis vraiment possédée... oui je vois le mort... les invisibles, je suis...."

"Ada apa denganku? Bodhi benar-benar kerasukan, ya Bodhi melihat orang-orang mati" (Rahimi, 2004: 153)

Perempuan juga dibuat menyesal dan ketakutan setelah ia bermasturbasi di depan suaminya terlebih juga ia menyentuh suaminya. Tidak hanya itu tetapi alasan perempuan bermasturbasi juga menghancurkan perlawanan perempuan itu sendiri. Jika perempuan bermasturbasi karena suaminya tidak dapat memberikan kepuasan dapat dikatakan adalah sebagai bentuk penghinaan terhadap kaum laki-laki namun di sini perempuan menjelaskan bahwa alasan ia bermasturbasi karena memang sudah sepantasnya ia bermasturbasi.

\section{Kesimpulan}

Rahimi ingin membela perempuan lewat syngué sabour. Hal ini dibuktikannya dengan 
memberikan kesempatan pada perempuan untuk berbicara. Perempuan Afganistan yang tidak memiliki ruang untuk berbicara karena kuatnya dominasi laki-laki sehingga Rahimi perlu membuat Rahimi koma. Dengan komanya laki-laki membuat perempuan memiliki ruang untuk berbicara, menceritakan kisahnya, keluh kesahnya, rahasianya, keinginannaya, serta hasratnya.

Pada novel ini dinarasikan bahwa perempuan yang lemah dalam dunia patriarkal ini sebenarnya memiliki kekuatan untuk melawan laki-laki. Akan tetapi, saat laki-laki koma membuktikan bahwa keadaan bisa berbalik. Jika saat laki-laki sadar, perempuanlah yang selalu dicaci maka keadaan koma lakilaki bisa membalikkan keadaan. Perlawanan perempuan pada laki-laki tidak hanya dengan cara menghina laki-laki, baik menghina secara verbal maupun dengan tindakan. Cacian yang dilontarkan perempuan mengukuhkan bahwa perempuan memiliki ruang untuk berkuasa atas laki-laki, atas tubuh laki-laki.

Tindakan-tindakan perempuan untuk mengelabuhi laki-laki juga merupakan sebuah usaha perlawanan perempuan pada dunia patriarkal. Jauh sebelum laki-laki koma atau tidak berdaya, perempuan dibuat kuat atau memiliki keberanian untuk melawan laki-laki oleh Rahimi. Namun demikian, perlawanan itu sebenarnya menunjukkan bahwa perempuan tetap tidak berdaya. Hal ini disebabkan dengan perlawanan perempuan yang bertujuan agar laki-laki tidak meninggalkannya karena bagaimana pun perempuan membutuhkan tetap membutuhkan laki-laki dan tidak dapat hidup tanpa laki-laki.

Sehingga dapat ditarik kesimpulan bahwa narasi perempuan yang ditulis Rahimi ternyata tidak membuktikan bahwa perempuan memiliki kekuasaan atas laki-laki walaupun lakilaki sedang koma. Perempuan tetaplah sebuah objek bagi laki-laki dan tidak memiliki kekuatan baik saat laki-laki sadar atau koma. Ruang yang diberikan pengarang untuk perempuan sebenarnya justru semakin mengukuhkan kekuasaan laki-laki. Sehingga dapat dikatakan bahwa apa yang dituliskan Rahimi dalam novel ini adalah sebuah iming-iming atau the lure of the image yang menurut Curti hanyalah sebuah gambaran perempuan yang diiming-iming kan pengarang pada perempuan.

Rahimi sebagai pengarang imigran yang mencoba menuliskan perempuan dengan bahasa Prancis mungkin juga pola pikir Prancis di mana perempuan tidaklah bukanlah sosok lemah. Sebagai feminis ia mencoba memberikan ruang bagi perempuan agar dapat melawan sistem patriarkal. Akan tetapi, pada kenyataannya ia masih terbawa oleh pola pikir asalnya, yaitu Afganistan. Hal ini terlihat di mana ia masih terjebak pada dua dunia seperti yang dikatakan oleh Lubecka bahwa seorang imigran masih akan terus terjebak pada dunia masa lalunya, yaitu negara yang ditinggalkannya dan dunia masa depannya yaitu negara yang ia tinggali saat ini. Perlawanan-perlawanan yang dilakukan perempuan hanyalah sebuah female gaze guna menyenangkan perempuan. Hal ini disebabkan karena Rahimi masih terjebak dalam pemikiran patriarkal Afganistan.

\section{Daftar Pustaka}

Almeida, José Dominique. 2012. Statut de La langue dans Syngué Sabour d'Atiq Rabimi. Université de Porto. Tidak diterbitkan.

2012. Ecriture au Feminin par Procuration. Université de Porto. Tidak diterbitkan.

Bal, Meike. 1999. Narratology Introduction to the Theory of Narrative. Toronto: Univerisy of Toronto Press

Cixous, Hélène. 2010. Le Rire de la Méduse. Paris: Galillé

Curti, Lidia. 1998. Female Bodiess, Female Stories, Narrative, Identity and Representation. London: Macmillan Press.

Darma, Dianda Budi \& Titik H. 2012. Confession without borders: 1 st Wave Feminism against Woman's Right Disproportion in Atiq rabimi's The Patience Stone. Surabaya: Universitas Negeri Surabaya. Tidak diterbitkan.

Faruk. 2012. Metode Penelitian Sastra: Sebuah Penjelajaban Awal. Yogyakarta: Pustaka Pelajar.

Irigaray, Luce. 1995. This Sex Which is not The 
One. New York: Cornell University Press.

Körömi. Gabriella. La symbolique des rideaux dans Syngué sabour d'Atiq Rahimi. Eger: École Supérieure Károly Eszterbzy. Tidak Diterbitkan.

Lanser, Susan S. 1986. Toward A Feminist Narratology. Pennsylvania: State University Press

Leese, Peter \& dkk. 2012. Migration, Narration, Identity: Cross-Cultural Perspective. Frankurt: Peter Lang Edition

Mustofa, Ali \& Rizki S. A. 2012. The Woman's Silent Voice toward Patriarchy's Handcuff reflected in Atiq Rabimi's The Patience Stone. Surabaya: Universitas Negeri Surabaya. Tidak diterbitkan.

Muvley, Laura. 1989. Visual and Other Pleasures. London: Macmillan

Rahimi, Atiq. 2008. Syngué Sabour, Pierre de
Patience. Paris: P.O.L .2012. Singge Sabur, Batu Kesabaran. Yogyakarta: Jalasutra

Sarup, Madan. 2003. Postrukuralisme dan Posmodernisme, Sebuah Pengantar Kritis. Yogyakarta: Penerbit Jendela

Tong, Rosemarie Putnam. 2004. Feminist Thought: Pengantar Paling Komprehensif kepada Aliran Utama Pemikiran Feminis. Yogyakarta: Jalasutra.

Wibowo. Agustinus. 2010. Selimut Debu, Imipian dan Kebanggaan dari Negeri Perang Afganistan. Jakarta: Gramedia Pustaka.

Winner, Irene Portis. 1984. Theories of Narration and Ethnic Culture Texts. Dalam Sign, System and Function. Proceedings of the First and Second Polish American Semiotics Colloquia (hal. 439455). Berlin New York Amsterdam: Mouton. 